\title{
Extraction Methods' Effects on Aflatoxin Concentration during Sunflower Oil Processing: First Report
}

\author{
Iş1 Var and Okşan Uçkun
}

\section{ABSTRACT}

Sunflower oil is one of the most known edible vegetable oil in the world. Although there are few studies on the presence of aflatoxin in sunflower seeds there are no studies on aflatoxin transfer to sunflower oil. In this study, not only was it demonstrated that there could be a toxin transfer from aflatoxin-contaminated raw materials to the oil, but it was also investigated how the extraction methods used for oil extraction from oilseeds affect the amount of aflatoxin transferred to the oil. Sunflower seeds, which are aflatoxin free were spiked 5 and $10 \mu \mathrm{g} / \mathrm{kg}$ and oil extraction was performed. It was found the transfer of aflatoxin to the oil was statistically significant in terms of the methods and amounts of inoculation $(p<0.05)$. The amount of total aflatoxin retained in the oil obtained from the sunflower seeds spiked with $5 \mu \mathrm{g} / \mathrm{kg}$ and $10 \mu \mathrm{g} / \mathrm{kg}$ of aflatoxins were respectively, $2.76(55.2 \%)$ and $5.77(57.7 \%) \mu \mathrm{g} / \mathrm{kg}$ in the cold press, $1.87(37.4 \%)$ and $4.69(46.9 \%) \mu \mathrm{g} / \mathrm{kg}$ in the press from roasted seeds, $0.91(18.2 \%)$ and $1.96(19.6 \%) \mu \mathrm{g} / \mathrm{kg}$ in the solvent (hexane) extraction. It was found that the best method is solvent (hexane) extraction for transfers the lowest aflatoxin to the oils.

Keywords: aflatoxin, extraction methods, oil, sunflower.
Submitted : October 01, 2021

Published : October 31, 2021

ISSN: $2684-1827$

DOI: $10.24018 /$ ejfood.2021.3.5.384

\section{Issıl Var*}

Faculty of Agriculture, Department of Food Engineering, Cukurova University, Adana, Turkey. (e-mail: ivar@cu.edu.tr)

\section{Okșan Uçkun}

Adana Food Control Laboratory Directorate, Adana, Turkey.

(e-mail: uckun_oksan ${ }^{\circledR}$ hotmail.com)

*Corresponding Author

\section{INTRODUCTION}

Sunflower (Helianthus annuus L.) is an annual ornamental plant grown as an oilseed crop [1]. Due to its chemical composition and nutritional value, sunflower seed is considered to be an important source of lipids and proteins and is widely used in the production of edible oils and animal feeds [2]. Sunflower oil is the preferred oil in mainly Ukraine, Russia, Argentina, Turkey and many Europe, Asia and, South American countries [3].

Aflatoxins are secondary metabolites produced by toxigenic strains of Aspergillus flavus, Aspergillus parasiticus and rarely Aspergillus nomius [4]. Aflatoxins, which have toxic, carcinogenic and mutagenic activity, cause serious health problems and economic losses when they contaminate food and feed materials [5].

Aflatoxins are commonly found in nuts, peanuts, corn, cottonseed, and other oil seeds. Although there are many studies on aflatoxin in peanut and hazelnut, there are limited studies on the presence of aflatoxins in sunflowers, such as those conducted on aflatoxin contamination in sunflower seeds, [2]-[6] or in sunflower seed products [7]-[8]. Sunflower seeds are a good substrate for aflatoxin production. While it is known that lipids play an important role in aflatoxin biosynthesis, unsaturated fatty acids in sunflowers also appear to have a strong effect on aflatoxin production [9]. Beheshti and Asadi [2] detected an average of $40.68 \mu \mathrm{g} / \mathrm{kg}$ of aflatoksin $\mathrm{B}_{1}\left(\mathrm{AFB}_{1}\right)$ in eight sunflower seed samples. Dawar and Ghaffar [6] detected the presence of aflatoxins in 13 of 24 sunflower seed samples collected from different regions of Pakistan and determined the highest amount of an aflatoxin to be $437 \mu \mathrm{g} / \mathrm{kg}$. In fact, the possible consequent presence of aflatoxins in sunflower seeds can lead to their transfer into oil. Mariod and Idris [10] detected $\mathrm{AFB}_{1}$ in amounts ranging from 0.7-35 $\mu \mathrm{g} / \mathrm{kg}$ in sunflower oil samples collected from various regions of Sudan. Researchers have reported that high aflatoxin contamination in oils may be due to the use of raw materials with high aflatoxin content.

In the production of crude oil from oil seeds, depending on the oil content of the raw material; mechanical pressing, solvent extraction, pre-pressing-solvent extraction, or twostage solvent extraction methods are used [11]. The differences in the characteristics of oleaginous material determine whether the recovery of the oil is performed via mechanical pressing, by the use of solvents or a combination of both methods. Once it uses a raw material contaminated with fungus and aflatoxin in both mechanical and solvent extraction of oil, the aflatoxins present can pass more or less into the oil as well as cake depending on the nature of the extraction [11]. Some studies on peanut oil extraction have shown that $15-30 \%$ of aflatoxins pass into the extracted oil from aflatoxin-contaminated peanuts [12]-[13].

Crude sunflower oil is obtained from partially dehulled seeds by mechanical pressing followed by hexane extraction and water degumming [14]. In fact, although it was thought 
that there was aflatoxin in crude oil, it was predicted that after refining and other advanced processes, aflatoxin would not remain in oils. But, lately, several reports from China, Sudan, India and Sri Lanka have shown that there are high incidences of aflatoxin contamination, especially in plantderived oils, in these regions [11].

Therefore, in this study focused on oil which obtained from raw materials contaminated with aflatoxin and evaluation of the process affect during the oil process.

\section{MATERIAL AND METHODS}

\section{A. Sunflower Seed Samples}

Sunflower samples used as material in this study were obtained from 10 different producers in Çukurova Region in $1 \mathrm{~kg}$ packages in 2017 and 2018 . The samples were stored in a deep freezer at $-18{ }^{\circ} \mathrm{C}$ until analyzed.

\section{B. Chemicals and Reagents}

A certified aflatoxin mix standard with a concentration of $2600 \mu \mathrm{g} / \mathrm{kg}$ consisting of 5 ampoules of $1 \mathrm{~mL}$ of $46304 \mathrm{U}$ brand was used (Supelco Aflatoxin Mix Kit-M Cat containing $1000 \mu \mathrm{g} / \mathrm{kg} \mathrm{B}, 300 \mu \mathrm{g} / \mathrm{kg} \mathrm{B}, 1000 \mu \mathrm{g} / \mathrm{kg} \mathrm{G}_{1}$, $300 \mu \mathrm{g} / \mathrm{kg} \mathrm{G}_{2}$ ). Methanol, acetonitrile, potassium bromide, sodium chloride and nitric acid were supplied by Merck (Darmstadt, Germany).

\section{Analysis of Aflatoxins in Sunflower Seeds}

The AOAC Official Method 999.31 [15] was used to detect aflatoxins in sunflower seed samples. $25 \mathrm{~g}$ of a sample and $5 \mathrm{~g}$ of $\mathrm{NaCl}$ were stirred with $125 \mathrm{~mL}$ of methanol:water (87.5:37.5) at high speed for $2 \mathrm{~min}$. After passing the mixture through 24-cm fluted filter paper (Vicam, Watertown, MA, USA), $15 \mathrm{~mL}$ of the extract was diluted with $30 \mathrm{~mL}$ purified water. Then, $15 \mathrm{~mL}$ of the extract which was filtered through a microfiber glass filter (934-AH, Maidstone, UK) was passed through an immunoaffinity column (IAC) containing monoclonal antibody specific for $\mathrm{AFB}_{1}, \mathrm{AFB}_{2}$, aflatoksin $\mathrm{G}_{1}\left(\mathrm{AFG}_{1}\right)$, and aflatoksin $\mathrm{G}_{2}\left(\mathrm{AFG}_{2}\right)$ to a flow of 1 drop per second. (934-AH, Maidstone, UK). Then, washing was performed by passing $10 \mathrm{~mL}$ of deionized water two times through the column with a flow rate not exceeding $5 \mathrm{~mL} / \mathrm{min}$. Aflatoxins were eluted from the column with $1.0 \mathrm{~mL}$ of methanol and $1.0 \mathrm{~mL}$ of deionized water, and then were determined for $\mathrm{AFB}_{1}, \mathrm{AFB}_{2}, \mathrm{AFG}_{1}$ and $\mathrm{AFG}_{2}$ by High Pressure Liquid Chromatography- Fluorescence Detector (HPLC-FLD).

\section{HPLC-FLD Determination of Aflatoxins}

The separation and quantification of aflatoxins was performed by an Agilent 1100 series HPLC system consisting of a G1310A isocratic pump, a G1313A autosampler, a G1316A column oven, a G1321A fluorescence detector model, and a G1379A degasser (Agilent Technologies, Palo Alto, California). The chromatographic column was kept in the oven at $25^{\circ} \mathrm{C}$ on a silica $5 \mathrm{~mm}$ ACE $5 \mathrm{C} 18,100 \AA$, 25x4.6 mm column supplied by Advanced Chromatography Technologies (Aberdeen, Scotland). The mobile phase consisted of water:methanol:acetonitrile $\quad(6: 3: 2, \quad \mathrm{v}: \mathrm{v}: \mathrm{v}), \quad$ potassium bromide $(120 \mathrm{mg} / \mathrm{L})$, and nitric acid $(350 \mu \mathrm{L} / \mathrm{L})$ isocratically delivered at a flow rate of $1 \mathrm{~mL} / \mathrm{min}$. The injection volume was $100 \mu \mathrm{L}$ into the HPLC system for both standard and sample. The fluorescence detector was set to an excitation wavelength of $360 \mathrm{~nm}$ and an emission wavelength of $430 \mathrm{~nm}$. The retention times were approximately $10 \mathrm{~min}$ for $\mathrm{AFG}_{2}, 12 \mathrm{~min}$ for $\mathrm{AFG}_{1}, 14 \mathrm{~min}$ for $\mathrm{AFB}_{2}$, and $17 \mathrm{~min}$.for $\mathrm{AFB}_{1}$.

The limit of detection (LOD) and limit of quantification (LOQ) of the analytical method were calculated according to the EURACHEM Guide based on data of the recovery experiment. [16] For the LOD and LOQ study, blank samples were spiked with $0.5 \mu \mathrm{g} / \mathrm{kg}$ for $\mathrm{AFB}_{1}$ and $\mathrm{AFG}_{1}$ and $0.15 \mu \mathrm{g} / \mathrm{kg}$ for $\mathrm{AFB}_{2}$ and $\mathrm{AFG}_{2}$ for each analyte and measured in 40 independent replicates. The LODs and LOQs were calculated using the following relations:

$$
\begin{gathered}
\mathrm{LOD}=\mathrm{x}+3 \mathrm{~s} \\
\mathrm{LOQ}=\mathrm{x}+10 \mathrm{~s}
\end{gathered}
$$

in which, " $x$ " is the mean concentration of fortified sample blank values, and "s" is the sample standard deviation.

An aflatoxin standard solution containing $1 \mu \mathrm{g} / \mathrm{kg} \mathrm{AFB}_{1}$, $0.3 \mu \mathrm{g} / \mathrm{kg} \mathrm{AFB} 2,1 \mu \mathrm{g} / \mathrm{kg} \mathrm{AFG}$, and $0.3 \mu \mathrm{g} / \mathrm{kg} \mathrm{AFG} \mathrm{Ag}_{2}$ was added to aflatoxin-free samples to determine the recovery values of aflatoxins in oil and cakes. The observed signal was plotted against the actual concentration.

The measured concentration was determined using the obtained calibration curves and the recovery value was calculated by the following equation:

$$
\begin{gathered}
\% \text { recovery }=100 \times \text { measured concentration for sample } \\
\text { spiked concentration }
\end{gathered}
$$

\section{E. Standard Solution Preparation}

Standard solutions at 5 different concentrations were used to generate the calibration curve. For this purpose, while aflatoxin standard solutions at 0.075, 0.15, 0.3, 0.6 and $1.2 \mu \mathrm{g} / \mathrm{kg}$ levels were used for $\mathrm{AFB}_{2}$ and $\mathrm{AFG}_{2}$, for $\mathrm{AFB}_{1}$ and $\mathrm{AFG}_{1}$, aflatoxin standards at $0.25,0.5,1,2$ and $4 \mu \mathrm{g} / \mathrm{kg}$ levels.

\section{F. Spiking of aflatoxin standard to sunflower seeds}

Spiking of aflatoxin standard was done to sunflower seeds according to Das and Mishra [17].

Samples inoculated at two different concentrations at $5 \mu \mathrm{g} / \mathrm{kg}$ and $10 \mu \mathrm{g} / \mathrm{kg}$ levels were left in dark and cold conditions for about 2 hours.

\section{G. Oil Extraction with Solvent Extraction Method}

Velp Scientifica Solvent Extractor, SER 148 Series was used in the extraction process. $25 \mathrm{~g}$ of weighed sunflower seed samples spiked with $5 \mu \mathrm{g} / \mathrm{kg}$ and $10 \mu \mathrm{g} / \mathrm{kg}$ of aflatoxins were ground in a blender and finely powdered. The sample was quantitatively transferred to the cartridge of a Soxhelet apparatus and sealed with a cotton pad. A sufficient amount of hexane was added to the extraction vessel and then extracted. Extraction was carried out for 60 minutes at $180^{\circ} \mathrm{C}$ and washing for 60 minutes. Oil samples were kept in the oven at $103{ }^{\circ} \mathrm{C}$ for 1 hour to remove the hexane after extraction. Then, aflatoxin analyses were performed in the 
obtained oils and oil cakes.

\section{H. Oil Extraction with Cold Press and Oil Extraction with Press from Roasted Seeds}

For both cold press oil extraction and press oil extraction from roasted seeds (the samples were weighed and mixed with aflatoxins, then roasted in the oven at $90{ }^{\circ} \mathrm{C}$ for 10 minutes), the sunflower seed samples were weighed as $100 \mathrm{~g}$, and then the aflatoxins were inoculated at rates of 5 and $10 \mu \mathrm{g} / \mathrm{kg}$ and extracted by mechanical pressing (Karaerler brand (NF 500) press machine). Aflatoxin analysis was performed for the oils and oil cakes obtained after the press.

\section{Analysis of Aflatoxins in Sunflower Oils Obtained by three Extraction Methods}

The determination of aflatoxins in oils was carried out on the HPLC-FLD according to the method recommended by Bao et al. [18] A solution of $25 \mathrm{~mL}$ of methanol + water $(55: 45, \mathrm{v}: \mathrm{v})$ and $1 \mathrm{~g}$ of $\mathrm{NaCl}$ was added to a $5 \mathrm{~g}$ sample and shaken at $400 \mathrm{rpm}$ for $10 \mathrm{~min}$. The mixture was then centrifuged at $7000 \mathrm{rpm}$ for $10 \mathrm{~min}$ to separate the oily layer. The supernatant was removed and filtered through Whatman No: 4 filter paper. $15 \mathrm{~mL}$ of the extract was diluted with $30 \mathrm{~mL}$ purified water. Then, $30 \mathrm{~mL}$ of the extract which was filtered through a microfiber glass filter was passed through an IAC containing monoclonal antibody specific for AFB1, AFB2, AFG1, and AFG2 to a flow of 1 drop per second. Then, washing was performed by passing $10 \mathrm{~mL}$ of deionized water 2 times through the column with a flow rate not exceeding $5 \mathrm{~mL} / \mathrm{min}$. Aflatoxins were eluted from the column with $1.0 \mathrm{~mL}$ of methanol and $1.0 \mathrm{~mL}$ of deionized water, and then were determined for $\mathrm{AFB}_{1}, \mathrm{AFB}_{2}$, $\mathrm{AFG}_{1}$ and $\mathrm{AFG}_{2}$ by an HPLC-FLD.

\section{J. Aflatoxin Analysis of Sunflower Oil Cakes Obtained by the Three Extraction Methods}

Aflatoxin analysis was performed according to the modified AOAC Official Method 999.31 [15]. $50 \mathrm{~g}$ of samples was weighed into a blender sample dish $5 \mathrm{~g}$ of $\mathrm{NaCl}$ was added. $100 \mathrm{ml}$ of methanol:water (80:20) was added and stirred at high $\mathrm{rpm}$ for $1 \mathrm{~min}$. After the extract was passed through coarse filter paper, $10 \mathrm{ml}$ of extract was taken and mixed with $40 \mathrm{ml}$ of pure water. The mixture was filtered through a microfiber glass filter. $10 \mathrm{ml}$ of sample extract was passed through the immunoaffinity column at a rate of 1-2 drops/second. Then, washing was performed by passing $10 \mathrm{~mL}$ of deionized water two times through the column with a flow rate not exceeding $5 \mathrm{~mL} / \mathrm{min}$. Air was passed through the column a few times to remove the water completely. $1 \mathrm{ml}$ of methanol and $1 \mathrm{ml}$ of water were passed through the immunoaffinity column and the resulting filtrate was thoroughly mixed with vortex and transferred to the HPLC-FLD.

\section{K. Statistical Analysis}

Statistical analysis was performed by one-way analysis of variance (ANOVA) using the SPSS 22.0 software package program. Duncan multiple comparisons were performed to determine significant differences between extraction methods. Values of $\mathrm{p}<0.05$ were regarded as significant.

\section{RESUlT AND DisCUSSION}

\section{A. Method Performance}

Aflatoxin standard solutions prepared at different concentrations for the calibration were injected into the HPLC device. Five different concentrations of $0.25,0.50,1$, 2 , and $4 \mu \mathrm{g} / \mathrm{kg}$ for $\mathrm{AFB}_{1}$ and $\mathrm{AFG}_{1}$, and five concentrations of $0.075,0.15,0.3,0.6$, and $1.2 \mu \mathrm{g} / \mathrm{kg}$ for $\mathrm{AFB}_{2}$ and $\mathrm{AFG}_{2}$ were used in the calibration. A calibration curve was created from five different points using the Chemstation software (Agilent) package program according to the peak areas corresponding to the aflatoxin standards injected into the HPLC column. The calibration curves revealed good linearity for all analytes in related concentration ranges, with coefficient of determination greater than 0.999. The linear regression equation, coefficient of determination $\left(\mathrm{R}^{2}\right)$ and residual standard deviation (RSD) for each analyte are given in Table I. Calibration curves of $\mathrm{AFG}_{2}, \mathrm{AFG}_{1}, \mathrm{AFB}_{2}, \mathrm{AFB}_{1}$ are shown in Fig. 1, Fig. 2, Fig. 3, and Fig. 4 at below, respectively.

\begin{tabular}{cccc} 
TABLE I: LINEARITY DATA FOR AFLATOXINS \\
\hline Analyte & $\begin{array}{c}\text { Linear regression } \\
\text { equation }\end{array}$ & $\begin{array}{c}\text { Linear } \\
\text { correlation } \\
\text { coefficient }\left(\mathrm{R}^{2}\right)\end{array}$ & $\begin{array}{c}\text { Residual standard } \\
\text { deviation (RSD\%) }\end{array}$ \\
\hline $\mathrm{AFB}_{1}$ & $\mathrm{Y}=5.73 \mathrm{x}+0.10$ & 0.99998 & 3.932 \\
$\mathrm{AFB}_{2}$ & $\mathrm{Y}=9.46 \mathrm{x}+0.07$ & 0.99984 & -10.182 \\
$\mathrm{AFG}_{1}$ & $\mathrm{Y}=3.55 \mathrm{x}+0.07$ & 0.99995 & -4.547 \\
$\mathrm{AFG}_{2}$ & $\mathrm{Y}=3.74 \mathrm{x}+0.06$ & 0.99941 & -3.432 \\
\hline
\end{tabular}

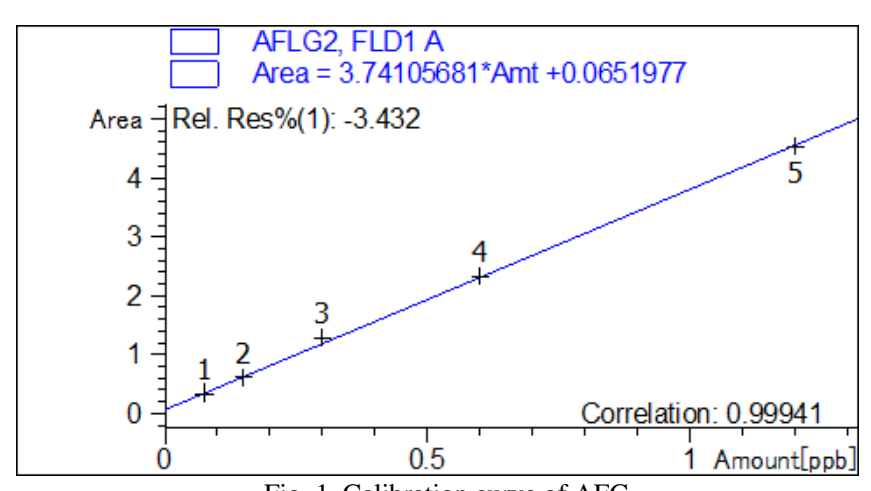

Fig. 1. Calibration curve of $\mathrm{AFG}_{2}$.

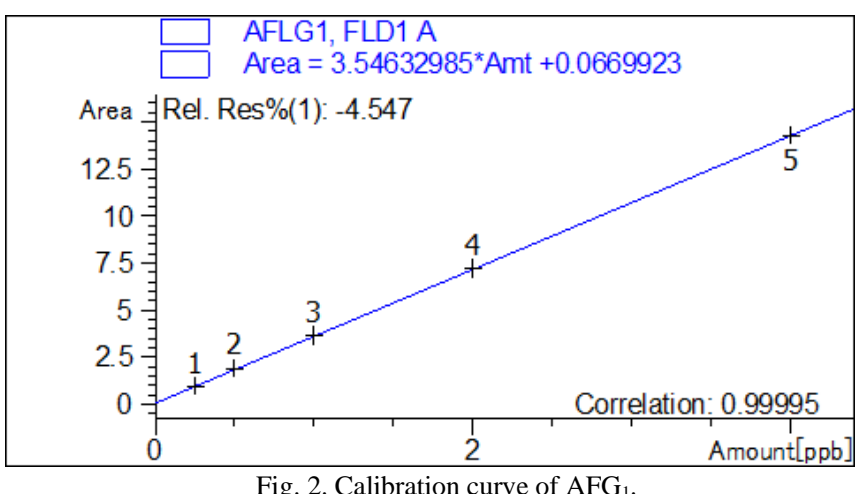

Fig. 2. Calibration curve of $\mathrm{AFG}_{1}$. 


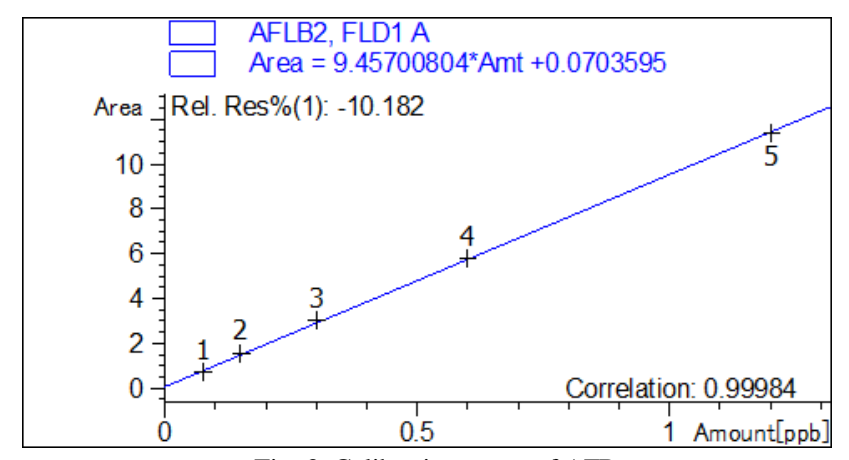

Fig. 3. Calibration curve of $\mathrm{AFB}_{2}$.

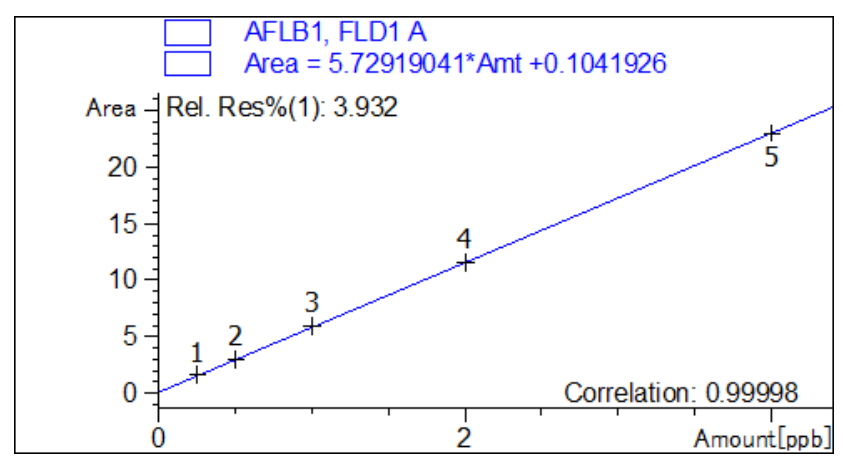

Fig. 4. Calibration curve of $\mathrm{AFB}_{1}$.

The LODs were found as $0.14 \mu \mathrm{g} / \mathrm{kg}$ for $\mathrm{AFB}_{1}, 0.06$ $\mu \mathrm{g} / \mathrm{kg}$ for $\mathrm{AFB}_{2}, 0.14 \mu \mathrm{g} / \mathrm{kg}$ for $\mathrm{AFG}_{1}$, and $0.05 \mu \mathrm{g} / \mathrm{kg}$ for $\mathrm{AFG}_{2}$. As well, LOQs were determined as $0.50 \mu \mathrm{g} / \mathrm{kg}$ for $\mathrm{AFB}_{1}, 0.23 \mu \mathrm{g} / \mathrm{kg}$ for $\mathrm{AFB}_{2}, 0.48 \mu \mathrm{g} / \mathrm{kg}$ for $\mathrm{AFG}_{1}$, and 0.20 $\mu \mathrm{g} / \mathrm{kg}$ for $\mathrm{AFG}_{2}$. The LODs and LOQs of the global method, the results of recovery are summarized in Table II.

TABLE II: METHOD PERFORMANCE CHARACTERISTICS FOR AFLATOXINS

\begin{tabular}{|c|c|c|c|c|c|}
\hline \multicolumn{6}{|c|}{ IN OIL AND OIL CAKES } \\
\hline \multirow[t]{2}{*}{ Analyte } & \multirow{2}{*}{$\begin{array}{l}\text { Spiking level } \\
(\mu \mathrm{g} / \mathrm{kg})\end{array}$} & \multicolumn{2}{|c|}{ Mean recovery $(\%)$} & \multirow{2}{*}{$\begin{array}{l}\mathrm{LOD}^{\mathrm{a}} \\
(\mu \mathrm{g} / \mathrm{kg})\end{array}$} & \multirow{2}{*}{$\begin{array}{c}\mathrm{LOQ}^{\mathrm{b}} \\
(\mu \mathrm{g} / \mathrm{kg})\end{array}$} \\
\hline & & Oil & Oil cake & & \\
\hline \multirow{2}{*}{$\mathrm{AFB}_{1}$} & 1 & \multirow{2}{*}{90} & \multirow{2}{*}{95} & \multirow{2}{*}{0.14} & \multirow{2}{*}{0.50} \\
\hline & 0.5 & & & & \\
\hline $\mathrm{AFB}_{2}$ & $\begin{array}{c}0.3 \\
0.15\end{array}$ & 83 & 82 & 0.06 & 0.23 \\
\hline $\mathrm{AFG}_{1}$ & $\begin{array}{c}1 \\
0.5\end{array}$ & 89 & 102 & 0.14 & 0.48 \\
\hline $\mathrm{AFG}_{2}$ & $\begin{array}{c}0.3 \\
0.15\end{array}$ & 90 & 97 & 0.05 & 0.20 \\
\hline
\end{tabular}

a LOD, limit of detection of the chromatographic method.

b LOQ, limit of quantification of the chromatographic method.

Afsah-Hejri et al. [19] spiked aflatoxin-free samples of peanuts with aflatoxins at the levels of $0.5 \mu \mathrm{g} / \mathrm{kg}$ (for $\mathrm{AFB}_{1}$ and $\mathrm{AFG}_{1}$ ) and $0.15 \mu \mathrm{g} / \mathrm{kg}$ (for $\mathrm{AFB}_{2}$ and $\mathrm{AFG}_{2}$ ). They found the LODs as $0.03 \mu \mathrm{g} / \mathrm{kg}$ for $\mathrm{AFB}_{1}, 0.01 \mu \mathrm{g} / \mathrm{kg}$ for $\mathrm{AFB}_{2}, 0.09 \mu \mathrm{g} / \mathrm{kg}$ for $\mathrm{AFG}_{1}$, and $0.06 \mu \mathrm{g} / \mathrm{kg}$ for $\mathrm{AFG}_{2}$. As well, they determined the LOQs as $0.10 \mu \mathrm{g} / \mathrm{kg}$ for $\mathrm{AFB}_{1}$, $0.04 \mu \mathrm{g} / \mathrm{kg}$ for $\mathrm{AFB}_{2}, 0.30 \mu \mathrm{g} / \mathrm{kg}$ for $\mathrm{AFG}_{1}$, and $0.20 \mu \mathrm{g} / \mathrm{kg}$ for $\mathrm{AFG}_{2}$. The data obtained in our study are similar to the data obtained in this study of Afsah-Hejri et al. [19]

The recovery values were found as $90 \%, 83 \%, 89 \%$, and $90 \%$ for $\mathrm{AFB}_{1}, \mathrm{AFB}_{2}, \mathrm{AFG}_{1}$ and $\mathrm{AFG}_{2}$, respectively, in the oil samples. Similarly, Bao et al. [18] recovered aflatoxins from peanut oil by $\mathrm{AFB}_{1} 86 \%(1 \mu \mathrm{g} / \mathrm{kg}), \mathrm{AFB}_{2} 94 \%$ $(0.25 \mu \mathrm{g} / \mathrm{kg}), \mathrm{AFG}_{1} 94 \%(0.5 \mu \mathrm{g} / \mathrm{kg})$, and $\mathrm{AFG}_{2} 85 \%$ $(0.25 \mu \mathrm{g} / \mathrm{kg})$.

The recovery values of oil cakes were determined as $95 \%$, $82 \%, 102 \%$, and $97 \%$ for $\mathrm{AFB}_{1}, \mathrm{AFB}_{2}, \mathrm{AFG}_{1}$, and $\mathrm{AFG}_{2}$, respectively.
Mmongoyo et al. [20] spiked sunflower seed oil cake with $\mathrm{AFB}_{1}$ at the levels of $10 \mu \mathrm{g} / \mathrm{kg}$ and $25 \mu \mathrm{g} / \mathrm{kg}$, and they recovered aflatoxins from that cake at $80 \%$ and $78 \%$. It is seen that this information supports the data we got in our research.

The data obtained from recovery as a result of the conducted studies are in good agreement with the Commission Regulation (EC) No 401/2006 [21] performance criteria for quantitative methods of mycotoxin analysis. It is stated that recovery rates of $50-120 \%$ at the concentration range of $<1 \mathrm{mg} / \mathrm{kg}$ and $70-110 \%$ at concentrations of $1-10 \mathrm{mg} / \mathrm{kg}$ for target analytes are acceptable.

\section{B. Amounts of Transfer of Aflatoxins to Sunflower Oils}

Since aflatoxins could not be detected in the sunflower seed samples, the study was performed with only aflatoxinspiked samples.

The amounts of aflatoxin in the oil obtained by three different extraction methods from sunflower seeds spiked in two different concentrations are given in Table III.

TABLE III: AFLATOXIN AMOUNTS IN OILS OBTAINED FROM SPIKED SUNFLOWER SEEDS

\begin{tabular}{|c|c|c|c|c|}
\hline & & $\begin{array}{c}\text { Cold press } \\
(\text { mean } \pm \text { SD) }\end{array}$ & $\begin{array}{c}\text { Press from } \\
\text { roasted seeds } \\
(\text { mean } \pm \mathrm{SD})\end{array}$ & $\begin{array}{c}\text { Solvent } \\
\text { extraction } \\
(\text { mean } \pm \text { SD })\end{array}$ \\
\hline \multirow[t]{2}{*}{$\overline{\mathrm{AFG}_{2}}$} & $5 \mu \mathrm{g} / \mathrm{kg}$ & $0.25^{\mathrm{A}} \pm 0.02$ & $0.15^{\mathrm{A}} \pm 0.03$ & $0.07^{\mathrm{B}} \pm 0.01$ \\
\hline & $10 \mu \mathrm{g} / \mathrm{kg}$ & $0.42^{\mathrm{A}} \pm 0.01$ & $0.36^{\mathrm{B}} \pm 0.02$ & $0.37^{\mathrm{B}} \pm 0.04$ \\
\hline \multirow[t]{2}{*}{$\mathrm{AFG}_{1}$} & $5 \mu \mathrm{g} / \mathrm{kg}$ & $0.94^{\mathrm{A}} \pm 0.05$ & $0.66^{\mathrm{B}} \pm 0.07$ & $0.14^{\mathrm{C}} \pm 0.01$ \\
\hline & $10 \mu \mathrm{g} / \mathrm{kg}$ & $2.01^{\mathrm{A}} \pm 0.47$ & $1.66^{\mathrm{A}} \pm 0.27$ & $0.36^{\mathrm{B}} \pm 0.09$ \\
\hline \multirow[t]{2}{*}{$\mathrm{AFB}_{2}$} & $5 \mu \mathrm{g} / \mathrm{kg}$ & $0.37^{\mathrm{A}} \pm 0.01$ & $0.26^{\mathrm{B}} \pm 0.01$ & $0.12^{\mathrm{C}} \pm 0.01$ \\
\hline & $10 \mu \mathrm{g} / \mathrm{kg}$ & $0.79^{\mathrm{A}} \pm 0.09$ & $0.59^{\mathrm{B}} \pm 0.04$ & $0.27^{\mathrm{C}} \pm 0.02$ \\
\hline \multirow[t]{2}{*}{$\mathrm{AFB}_{1}$} & $5 \mu \mathrm{g} / \mathrm{kg}$ & $1.20^{\mathrm{A}} \pm 0.13$ & $0.80^{\mathrm{B}} \pm 0.03$ & $0.58^{\mathrm{C}} \pm 0.02$ \\
\hline & $10 \mu \mathrm{g} / \mathrm{kg}$ & $2.55^{\mathrm{A}} \pm 0.03$ & $2.08^{\mathrm{B}} \pm 0.38$ & $0.96^{\mathrm{C}} \pm 0.10$ \\
\hline \multirow{2}{*}{$\begin{array}{l}\text { Total } \\
\text { AFL }\end{array}$} & $5 \mu \mathrm{g} / \mathrm{kg}$ & $2.76^{\mathrm{A}} \pm 0.25$ & $1.87^{\mathrm{B}} \pm 0.35$ & $0.91^{\mathrm{C}} \pm 0.02$ \\
\hline & $10 \mu \mathrm{g} / \mathrm{kg}$ & $5.77^{\mathrm{A}} \pm 0.27$ & $4.69^{\mathrm{B}} \pm 0.41$ & $1.96^{\mathrm{C}} \pm 0.18$ \\
\hline
\end{tabular}

SD: Standard deviation; A, B, C. The difference between the values shown in different letters in the same line is significant according to Duncan Multiple Comparison test $(\mathrm{p}<0.05)$.

As seen in Table III, aflatoxin amounts in oils obtained by three different extraction methods from sunflower seeds spiked with $5 \mu \mathrm{g} / \mathrm{kg}$ and $10 \mu \mathrm{g} / \mathrm{kg}$ of aflatoxins were found to be statistically significant $(\mathrm{p}<0.05)$ for $\mathrm{AFG}_{2}, \mathrm{AFG}_{1}$, $\mathrm{AFB}_{2}, \mathrm{AFB}_{1}$, and total aflatoxin. The amounts of aflatoxin in oil obtained by cold press from sunflower seeds spiked with $5 \mu \mathrm{g} / \mathrm{kg}$ of aflatoxins were found as $0.25 \mu \mathrm{g} / \mathrm{kg}$ for $\mathrm{AFG}_{2}, \quad 0.94 \mu \mathrm{g} / \mathrm{kg}$ for $\mathrm{AFG}_{1}, \quad 0.37 \mu \mathrm{g} / \mathrm{kg}$ for $\mathrm{AFB}_{2}$, $1.20 \mu \mathrm{g} / \mathrm{kg}$ for $\mathrm{AFB}_{1}$, and $2.76 \mu \mathrm{g} / \mathrm{kg}$ for total aflatoxin. As well, the aflatoxin amounts in oils from press of roasted seeds were found as $0.15 \mu \mathrm{g} / \mathrm{kg}$ for $\mathrm{AFG}_{2}, 0.66 \mu \mathrm{g} / \mathrm{kg}$ for $\mathrm{AFG}_{1}, 0.26 \mu \mathrm{g} / \mathrm{kg}$ for $\mathrm{AFB}_{2}, 0.80 \mu \mathrm{g} / \mathrm{kg}$ for $\mathrm{AFB}_{1}$ and $1.87 \mu \mathrm{g} / \mathrm{kg}$ for total aflatoxins. The amounts of aflatoxins in oils from solvent extraction were determined as $0.07 \mu \mathrm{g} / \mathrm{kg}$ for $\mathrm{AFG}_{2}, 0.14 \mu \mathrm{g} / \mathrm{kg}$ for $\mathrm{AFG}_{1}, 0.12 \mu \mathrm{g} / \mathrm{kg}$ for $\mathrm{AFB}_{2}$, $0.58 \mu \mathrm{g} / \mathrm{kg}$ for $\mathrm{AFB}_{1}$, and $0.91 \mu \mathrm{g} / \mathrm{kg}$ for total aflatoxins.

On the other hand, the amounts of aflatoxins in oil obtained by cold press from sunflower seeds spiked with $10 \mu \mathrm{g} / \mathrm{kg}$ of aflatoxins were found as $0.42 \mu \mathrm{g} / \mathrm{kg}$ for $\mathrm{AFG}_{2}$, $2.01 \mu \mathrm{g} / \mathrm{kg}$ for $\mathrm{AFG}_{1}, 0.79 \mu \mathrm{g} / \mathrm{kg}$ for $\mathrm{AFB}_{2}, 2.55 \mu \mathrm{g} / \mathrm{kg}$ for $\mathrm{AFB}_{1}$, and $5.77 \mu \mathrm{g} / \mathrm{kg}$ for total aflatoxins. As well $0.36 \mu \mathrm{g} / \mathrm{kg}$ for $\mathrm{AFG}_{2}, 1.66 \mu \mathrm{g} / \mathrm{kg}$ for $\mathrm{AFG}_{1}, 0.59 \mu \mathrm{g} / \mathrm{kg}$ for $\mathrm{AFB}_{2}, 2.08 \mu \mathrm{g} / \mathrm{kg}$ for $\mathrm{AFB}_{1}$, and $4.69 \mu \mathrm{g} / \mathrm{kg}$ for total 
aflatoxin amounts were found in oils from the press of roasted seeds. The amounts of aflatoxin in oils from solvent extraction were determined as $0.37 \mu \mathrm{g} / \mathrm{kg}$ for $\mathrm{AFG}_{2}$, $0.36 \mu \mathrm{g} / \mathrm{kg}$ for $\mathrm{AFG}_{1}, 0.27 \mu \mathrm{g} / \mathrm{kg}$ for $\mathrm{AFB}_{2}, 0.96 \mu \mathrm{g} / \mathrm{kg}$ for $\mathrm{AFB}_{1}$, and $1.96 \mu \mathrm{g} / \mathrm{kg}$ for total aflatoxins.

In both inoculations, it was found total aflatoxin transfer is the highest in the oils obtained by the cold press method. This was followed by the oils obtained by pressing the roasted seeds, and it was observed that aflatoxin transfer was lowest in the oils obtained by the solvent (hexane) extraction method. $18.2 \%(5 \mu \mathrm{g} / \mathrm{kg}$ spiked) and $19.6 \%$ $(10 \mu \mathrm{g} / \mathrm{kg}$ spiked) aflatoxin transfer to oil by the solvent (hexane) method was observed. Although aflatoxins are not soluble in non-polar solvents such as petroleum ether, propanol, or hexane, they can be dissolved in polar solvents such as chloroform, methanol, or ethanol [22]. Therefore, aflatoxin transition to oil obtained with hexane is thought to be lower.

In a study conducted by Parker and Melnick [13], it was found that the amount of aflatoxins decreased from $5500 \mu \mathrm{g} / \mathrm{kg}$ to $120 \mu \mathrm{g} / \mathrm{kg}$ in crude oil obtained by the solvent (hexane) extraction method of peanuts which contained $5.500 \mu \mathrm{g} / \mathrm{kg}$ of aflatoxins. In another study it was also reported that most of the aflatoxins were retained in oil cake and a small portion was transferred to oil [11]. Similar results were obtained in this study, where hexane was used in the solvent extraction process.

In this study it was observed $55.2 \%(5 \mu \mathrm{g} / \mathrm{kg}$ spiked $)$ and $57.7 \%(10 \mu \mathrm{g} / \mathrm{kg}$ spiked $)$ aflatoxin transition to oil by cold press. In this method, the aflatoxin content of the crude oil was found to be higher than that obtained by solvent extraction. It is thought that the reason why aflatoxin transfer to sunflower oil is higher is due to the pressing of sunflower with shell. The presence of the shell in the sunflower facilitated the pressing, so that more aflatoxin was transferred to the oil obtained.

In aflatoxin transfer to sunflower oil with press from roasted seeds, $37.4 \%$ (5 $\mu \mathrm{g} / \mathrm{kg}$ spiked) and $46.9 \%(10 \mu \mathrm{g} / \mathrm{kg}$ spiked) aflatoxin transfer to oil was observed. In this extraction method, sunflower seeds were roasted in the oven at $90{ }^{\circ} \mathrm{C}$ for 10 minutes before pressing. However, it was observed that these applied conditions were not sufficient to reduce aflatoxins. Yazdanpanah et al. [23] researched the effect on degradation of aflatoxins of roasting in contaminated pistachios, applying heat treatment at 90, 120, and $150{ }^{\circ} \mathrm{C}$ to pistachios. They reported that while the destruction of aflatoxins was $90 \%$ in samples roasted at $120^{\circ} \mathrm{C}$ for 120 minutes and $150{ }^{\circ} \mathrm{C}$ for $30-120$ minutes, aflatoxin degradation was lowest in samples roasted at $90{ }^{\circ} \mathrm{C}$ for 30 minutes. However, it was reported that roasting at $150^{\circ} \mathrm{C}$ for 120 minutes caused an undesirable burnt aroma in the pistachio. In a similar work, Pluyer et al. [24] reported that aflatoxin, which is naturally found in peanuts roasted for 30 minutes at $150{ }^{\circ} \mathrm{C}$, is reduced by only $30-45 \%$. The extent of the destruction of aflatoxins achieved is dependent on the initial level of contamination, temperature, heating time, and type of food [25]. Degradation of aflatoxins by heat is also governed by the moisture content, $\mathrm{pH}$, and ionic strength of the food. The moisture content is a critical factor: contaminated foods that contain more moisture can more easily be inactivated by heat [26]. In a study conducted by
Mann et al. [27] $74.8 \%$ of aflatoxins $\left(\mathrm{B}_{1}+\mathrm{B}_{2}\right)$ were degraded by heating at $100{ }^{\circ} \mathrm{C}$ for $1 \mathrm{~h}$ at a moisture content of $30 \%$ in contaminated cottonseed meal, while $32.7 \%$ degradation occurred in a similar meal containing $6.6 \%$ moisture, under similar conditions. It has been suggested that the presence of moisture in foods helps in opening the lactone ring in $\mathrm{AFB}_{1}$ to form a terminal carboxylic acid, which then undergoes heat-induced decarboxylation [28]. In sunflower seeds, it is stated that moisture should be $10-12 \%$ at most [29]. Accordingly, the relatively low humidity of sunflower seeds is thought to cause less aflatoxin degradation through roasting sunflower seeds. Also, the moisture content of oilseeds influences screw press performance. Low moisture content typically resulted in better oil yield [30]. It is thought that high oil yield causes more aflatoxins to pass into sunflower oil.

When comparing the inoculation amounts $(5 \mu \mathrm{g} / \mathrm{kg}$ and $10 \mu \mathrm{g} / \mathrm{kg}$ ) in this study, it was found that the highest transfer of aflatoxins was seen in the inoculation amount of $10 \mu \mathrm{g} / \mathrm{kg}$ in the three methods studied (solvent extraction, cold pressing and pressing of roasted seeds). As the initial amount of aflatoxins in the raw material increases, the amount of aflatoxin transfer into the oil may increase. Var et al. [31] in a study investigating the destruction of ochratoxin A in bread-making stages, found after the baking process $0.635 \mu \mathrm{g} / \mathrm{kg}$ in samples spiked with $5 \mu \mathrm{g} / \mathrm{kg}$ of aflatoxins, and $2.37 \mu \mathrm{g} / \mathrm{kg}$ in samples spiked with $10 \mu \mathrm{g} / \mathrm{kg}$. It is seen that the information obtained in this study supports the data we obtained in our research.

According to the Turkish Food Codex, [32] the aflatoxin limits for peanuts, other oilseeds, and their processed products which are directly offered to human consumption determined a maximum of $10 \mu \mathrm{g} / \mathrm{kg}$ for total aflatoxins, and $5 \mu \mathrm{g} / \mathrm{kg}$ for $\mathrm{AFB}_{1}$ [32]. In our study, our results remained below the limits because we chose $5 \mu \mathrm{g} / \mathrm{kg}$ and $10 \mu \mathrm{g} / \mathrm{kg}$ as the initial amounts of inoculation. However, the European Community established maximum limits of $4 \mu \mathrm{g} / \mathrm{kg}$ for total aflatoxins, and $2 \mu \mathrm{g} / \mathrm{kg}$ for $\mathrm{AFB}_{1}$ in groundnuts and all processed foods intended for direct human consumption [11]. While the amount of aflatoxin transferred to the oil obtained by press from $10 \mu \mathrm{g} / \mathrm{kg}$ aflatoxin spiked roasted sunflower seeds was found to be $4.69 \mu \mathrm{g} / \mathrm{kg}$, it was found to be $5.77 \mu \mathrm{g} / \mathrm{kg}$ by cold press. And these aflatoxin amounts were found to be above the limits mentioned in the regulation.

Although there are few studies that the presence of aflatoxin in sunflower seeds, there are no studies and reports on aflatoxin transfer to sunflower oil. But, in the study conducted by Mariod and Idris [10] determined $\mathrm{AFB}_{1}$ levels of 0.7 to $35 \mu \mathrm{g} / \mathrm{kg}$ in sunflower oils which were collected from different regions of Sudan. Researchers predicted and reported that high aflatoxin contamination of partially refined oils $(62 \%)$ may be due to an uncompleted refining process or use of raw oilseeds with high aflatoxin contamination.

As seen in these studies have shown that sunflower oils can be risky with respect to aflatoxin when consume as a crude oil or a partially refined oil. Already in our study, it was seen that there may be a risk in oils if the raw material is contaminated. Therefore, it is important that the raw material is clean in terms of aflatoxins in preventing the 
transfer of aflatoxins into the oil.

\section{The Amount of the Transfer of Aflatoxins into Sunflower Oil Cakes}

The amount of aflatoxin in the oilcakes was also examined in order to see how much aflatoxin amount was transferred from the oils obtained during oil extraction from sunflower seeds spiked with total aflatoxin at $5 \mu \mathrm{g} / \mathrm{kg}$ and $10 \mu \mathrm{g} / \mathrm{kg}$ concentrations to the remaining oilcakes.

TABLE IV: AFLATOXIN AMOUNTS IN Oil CAKES OBTAINED FROM SPIKED SUNFLOWER SEEDS

\begin{tabular}{ccccc}
\multicolumn{5}{c}{ SUNFLOWER SEEDS } \\
\hline & $\begin{array}{c}\text { Cold press } \\
(\text { mean } \pm \mathrm{SD})\end{array}$ & $\begin{array}{c}\text { Press from } \\
\text { roasted seeds } \\
(\text { mean } \pm \mathrm{SD})\end{array}$ & $\begin{array}{c}\text { Solvent } \\
\text { extraction } \\
(\text { mean } \pm \mathrm{SD})\end{array}$ \\
\hline $\mathrm{AFG}_{2}$ & $5 \mu \mathrm{g} / \mathrm{kg}$ & $0.22^{\mathrm{C}} \pm 0.01$ & $0.33^{\mathrm{B}} \pm 0.02$ & $0.51^{\mathrm{A}} \pm 0.03$ \\
& $10 \mu \mathrm{g} / \mathrm{kg}$ & $0.40^{\mathrm{B}} \pm 0.02$ & $0.57^{\mathrm{A}} \pm 0.03$ & $0.26^{\mathrm{C}} \pm 0.03$ \\
$\mathrm{AFG}_{1}$ & $5 \mu \mathrm{g} / \mathrm{kg}$ & $0.77^{\mathrm{C}} \pm 0.08$ & $0.85^{\mathrm{B}} \pm 0.05$ & $1.55^{\mathrm{A}} \pm 0.01$ \\
& $10 \mu \mathrm{g} / \mathrm{kg}$ & $1.22^{\mathrm{C}} \pm 0.05$ & $1.74^{\mathrm{B}} \pm 0.02$ & $3.43^{\mathrm{A}} \pm 0.02$ \\
$\mathrm{AFB}_{2}$ & $5 \mu \mathrm{g} / \mathrm{kg}$ & $0.24^{\mathrm{C}} \pm 0.05$ & $0.48^{\mathrm{B}} \pm 0.14$ & $0.56^{\mathrm{A}} \pm 0.03$ \\
& $10 \mu \mathrm{g} / \mathrm{kg}$ & $0.37^{\mathrm{C}} \pm 0.05$ & $0.57^{\mathrm{B}} \pm 0.03$ & $1.10^{\mathrm{A}} \pm 0.05$ \\
$\mathrm{AFB}_{1}$ & $5 \mu \mathrm{g} / \mathrm{kg}$ & $0.71^{\mathrm{C}} \pm 0.11$ & $1.09^{\mathrm{B}} \pm 0.24$ & $1.34^{\mathrm{A}} \pm 0.05$ \\
& $10 \mu \mathrm{g} / \mathrm{kg}$ & $1.10^{\mathrm{C}} \pm 0.04$ & $1.78^{\mathrm{B}} \pm 0.22$ & $2.94^{\mathrm{A}} \pm 0.05$ \\
Total AFL & $5 \mu \mathrm{g} / \mathrm{kg}$ & $1.94^{\mathrm{C}} \pm 0.12$ & $2.75^{\mathrm{B}} \pm 0.35$ & $3.96^{\mathrm{A}} \pm 0.18$ \\
& $10 \mu \mathrm{g} / \mathrm{kg}$ & $3.09^{\mathrm{C}} \pm 0.22$ & $4.66^{\mathrm{B}} \pm 0.23$ & $7.73^{\mathrm{A}} \pm 0.33$ \\
\hline
\end{tabular}

SD, Standard deviation; A, B, C. The difference between the values shown in different letters in the same line is significant according to Duncan Multiple Comparison test $(\mathrm{p}<0.05)$.

As seen in Table IV, aflatoxin amounts in oil cakes obtained with three different methods from sunflower seeds spiked with $5 \mu \mathrm{g} / \mathrm{kg}$ and $10 \mu \mathrm{g} / \mathrm{kg}$ of aflatoxins were found to be statistically significant $(\mathrm{p}<0.05)$ for $\mathrm{AFG}_{2}, \mathrm{AFG}_{1}$, $\mathrm{AFB}_{2}, \mathrm{AFB}_{1}$ and total aflatoxins. The amounts of aflatoxin transfer to the oil cake from sunflower seeds spiked with $5 \mu \mathrm{g} / \mathrm{kg}$ of aflatoxins by cold press were $0.22 \mu \mathrm{g} / \mathrm{kg}$ for $\mathrm{AFG}_{2}, 0.77 \mu \mathrm{g} / \mathrm{kg}$ for $\mathrm{AFG}_{1}, 0.24 \mu \mathrm{g} / \mathrm{kg}$ for $\mathrm{AFB}_{2}$, $0.71 \mu \mathrm{g} / \mathrm{kg}$ for $\mathrm{AFB}_{1}$; and for total aflatoxins it was $1.94 \mu \mathrm{g} / \mathrm{kg}$. Also, the amounts of aflatoxins in oil cakes from the press of roasted seeds were: $0.33 \mu \mathrm{g} / \mathrm{kg}$ for $\mathrm{AFG}_{2}$, $0.85 \mu \mathrm{g} / \mathrm{kg}$ for $\mathrm{AFG}_{1}, 0.48 \mu \mathrm{g} / \mathrm{kg}$ for $\mathrm{AFB}_{2}$, and $1.09 \mu \mathrm{g} / \mathrm{kg}$ for $\mathrm{AFB}_{1}$; for total aflatoxins it was $2.75 \mu \mathrm{g} / \mathrm{kg}$. Aflatoxin amounts in oil cakes from solvent extraction were determined to be $0.51 \mu \mathrm{g} / \mathrm{kg}$ for $\mathrm{AFG}_{2}, 1.55 \mu \mathrm{g} / \mathrm{kg}$ for $\mathrm{AFG}_{1}, 0.56 \mu \mathrm{g} / \mathrm{kg}$ for $\mathrm{AFB}_{2}, 1.34 \mu \mathrm{g} / \mathrm{kg}$ for $\mathrm{AFB}_{1}$, and $3.96 \mu \mathrm{g} / \mathrm{kg}$ for total aflatoxins.

The amounts of aflatoxins remaining in oil cakes obtained from sunflower seeds spiked with $10 \mu \mathrm{g} / \mathrm{kg}$ of aflatoxins by cold press were found to be $0.40 \mu \mathrm{g} / \mathrm{kg}$ for $\mathrm{AFG}_{2}$, $1.22 \mu \mathrm{g} / \mathrm{kg}$ for $\mathrm{AFG}_{1}, 0.37 \mu \mathrm{g} / \mathrm{kg}$ for $\mathrm{AFB}_{2}, 1.10 \mu \mathrm{g} / \mathrm{kg}$ for $\mathrm{AFB}_{1}$, and $3.09 \mu \mathrm{g} / \mathrm{kg}$ for total aflatoxins. In addition, the amounts of aflatoxins remaining in the oil cakes obtained from pressing the roasted seeds were determined to be at $0.57 \mu \mathrm{g} / \mathrm{kg}$ for $\mathrm{AFG}_{2}, 1.74 \mu \mathrm{g} / \mathrm{kg}$ for $\mathrm{AFG}_{1}, 0.57 \mu \mathrm{g} / \mathrm{kg}$ for $\mathrm{AFB}_{2}, 1.78 \mu \mathrm{g} / \mathrm{kg}$ for $\mathrm{AFB}_{1}$, and $4.66 \mu \mathrm{g} / \mathrm{kg}$ for total aflatoxins. The amounts of aflatoxins remaining in the oil cakes obtained by the solvent extraction method were $0.26 \mu \mathrm{g} / \mathrm{kg}$ for $\mathrm{AFG}_{2}, 3.43 \mu \mathrm{g} / \mathrm{kg}$ for $\mathrm{AFG}_{1}, 1.10 \mu \mathrm{g} / \mathrm{kg}$ for $\mathrm{AFB}_{2}, 2.94 \mu \mathrm{g} / \mathrm{kg}$ for $\mathrm{AFB}_{1}$, and $7.73 \mu \mathrm{g} / \mathrm{kg}$ for total aflatoxins.

In both inoculations, it was found total aflatoxin transfer was the highest in the oil cakes obtained by solvent (hexane) extraction. This was followed by the oil cakes obtained by pressing the roasted seeds and aflatoxin transfer was lowest in the oil cakes obtained by cold press.

In the solvent extraction method, it was observed that while most of the aflatoxin was transferred to the oil cake, less aflatoxin was transferred to the oil. Since hexane used in the solvent extraction method does not have the ability to extract aflatoxin, it is thought that most of the aflatoxin remains in the oil cake.

In the cold press method, it was observed that while most of the aflatoxin was transferred to the oil, less of it was transferred to the oil cake. In the cold press method, where more oil is reported to remain in the oil cake, aflatoxin can be expected to remain in the oil cake more. It is thought that the reason why aflatoxin is more transferred to the oil may be related to the pressing of sunflower with shell. The presence of hulls in sunflower seeds make them easier to press, so more aflatoxin is passed to the oil obtained, while less aflatoxin is found in the oil cake.

The European Economic Community (EEC) regulations allow maximum permitted levels for $\mathrm{AFB}_{1}$ at $20 \mu \mathrm{g} / \mathrm{kg}$ in feedstuffs derived from processing of groundnuts, copra, palm kernel, cottonseed, babassu, and maize [33]. Also, in Turkey maximum levels (max) of $\mathrm{AFB}_{1}$ are determined as $20 \mu \mathrm{g} / \mathrm{kg}$ for animal feeds, excluding complementary feeds. In the sunflower seeds spiked with $5 \mu \mathrm{g} / \mathrm{kg}$ and $10 \mu \mathrm{g} / \mathrm{kg}$, the amounts of $\mathrm{AFB}_{1}$ transferred to the oil cake was $1.34 \mu \mathrm{g} / \mathrm{kg}$ and $2.94 \mu \mathrm{g} / \mathrm{kg}$ in the solvent extraction method, $1.09 \mu \mathrm{g} / \mathrm{kg}$ and $1.78 \mu \mathrm{g} / \mathrm{kg}$ in the pressing of the roasted seeds, $0.71 \mu \mathrm{g} / \mathrm{kg}$ and $1.10 \mu \mathrm{g} / \mathrm{kg}$ in the cold pressing method, respectively. Since the initial amounts of aflatoxin in the study was chosen as $5 \mu \mathrm{g} / \mathrm{kg}$ and $10 \mu \mathrm{g} / \mathrm{kg}$, the amounts of aflatoxin that passed into the oil cake remain below the limits. However, it shows that when the initial amount of aflatoxin is over $10 \mu \mathrm{g} / \mathrm{kg}$, the amount of toxins passing to the oil cake may exceed the limits.

In the solvent (hexane) extraction method used in this study, the fact that most of the aflatoxin remains in the oil cake could affect the health of animals and indirectly human health through consumption of the animals' meat and milk. Various detoxification methods are applied to remove aflatoxins in oil cake in various studies. For this purpose, the most commonly used solvents in studies include $95 \%$ ethanol, $90 \%$ aqueous acetone, $80 \%$ isopropanol, hexanemethanol, methanol-water, acetonitrile-water, hexaneethanol-water, and acetone-hexane-water. While solvent extraction can effectively remove aflatoxin from oilseed meals without either the formation of toxic byproducts or any reduction in nutritional properties or quality, large-scale application of this technique is limited by high costs and problems related to disposal of the toxic extracts. Even though some polar solvents like methanol and ethanol are effective in the reduction of aflatoxins from contaminated commodities, there are problems with the additional coextraction of solids from these materials. For example, it has been reported that extraction with $80 \%$ isopropanol completely removed aflatoxins in cottonseed and peanut meal, but it also removed between $8.7 \%$ and $9.5 \%$ of meal solids [28].

Bordin et al. [11] recommend the use of presses for oil extraction for oil seeds with high oil content (above 35\%) such as flaxseed, cottonseed, sunflower, and corn. Researchers also reported that this type of extraction is simpler, safer and requires fewer processing steps compared with solvent extraction [11]. Oils obtained by cold press do 
not contain any chemical residues and the beneficial natural components found in the seed are not lost and remain in the oil. The cold pressing method, which does not require heat treatment or chemical treatment, has been reported to be more acceptable than the other methods due to consumers' desire for safe and natural food [34]. However, when the cold press method is evaluated in terms of toxins because aflatoxin passes into sunflower oil this method may be risky in terms of health.

\section{CONCLUSIONS}

This study indicated that aflatoxin transfer was lowest in the oils obtained by the solvent (hexane) method in both inoculations ( 5 and $10 \mu \mathrm{g} / \mathrm{kg}$ ). This is followed by the oils obtained by pressing the roasted seeds, and aflatoxin transfer was found to be highest in the oils obtained by the cold press method. It has been also shown that as the initial amount of aflatoxin in the raw material increases the amount of aflatoxin transition into the oil and oil cake increases as well.

This study is the first to demonstrate aflatoxin carry-over from sunflower into crude oil. Aflatoxin amounts in oils and oil cakes obtained with three different methods from $5 \mu \mathrm{g} / \mathrm{kg}$ and $10 \mu \mathrm{g} / \mathrm{kg}$ of spiked sunflower were found to be statistically significant $(p<0.05)$. It was determined that through solvent (hexane) extraction most of the aflatoxins were retained in the oil cake and a small portion was transferred to the oil. However, it was reported that largescale application of this technique in industry is limited because of high costs and problems related to disposal of the toxic extracts. In addition, although the amount of aflatoxin passed into the oil in the solvent extraction method is low, it was seen that the rest of the aflatoxins passed into the oil cake. This would indirectly affect consumers' health through to animal products such as meat and milk if these oil cakes are used as animal feed without any detoxification. When we evaluate the press methods, it was found that this type of extraction is simpler, safer and requires fewer steps compared with solvent extraction. As well, the use of presses for oil extraction has also been recommended for materials with high oil content (above 35\%) such as flaxseed, cottonseed, sunflower, and corn. In this study, however, it was determined that neither press with roasted seeds nor cold press methods could block transfer of aflatoxins into the oil. Aflatoxins decompose at increased temperatures ranging from 237 to $306{ }^{\circ} \mathrm{C}$. Therefore, aflatoxins were not completely destroyed by extraction, and were carried along from seeds to oil samples. So far, it is estimated that the presence of aflatoxin in oils could be affected by the refining process. However, previous studies showed that it could be the presence of aflatoxins in the oils collected from the market. That also means that if this refining process is not applied properly, it would not be possible to produce safe edible oil for humans. In addition, it is important that the raw material is clean in terms of aflatoxins in preventing the passage of aflatoxins into edible oil in products such as olive oil consumed as virgin oil. Therefore, it is important using clean and qualty raw material, and GMP (good manufacture process) application which helps food safety and public health.

\section{ACKNOWLEDGMENT}

The authors would like to thank The Scientific and Technical Research Council of Turkey (TUBITAK, Project No. 1180544) and Cukurova University Department of Scientific Research Projects (FDK-2016-6966) which funded this project.

\section{CONFLICTS OF INTEREST}

The authors declare that this work has not been published previously and there are no conflicts of interest. The authors declare no conflicts of interest.

\section{REFERENCES}

[1] S. Nahar, M. Mushtaq, and M.H. Hashmi, "Seed-borne mycoflora of sunflower (Helianthus Annuus L.)," Pak. J. Bot, vol.37, no. 2, pp. 451-457, 2005.

[2] H.R. Beheshti and M. Asadi, "Aflatoxins in sunflower and safflower seeds from Iran," Food Addit. Contam. Part, vol. 6, no.1, pp. 68-71, 2013.

[3] FAO. Food and Agriculture Organization of the United Nations Web Address (http://www.fao.org), 2018.

[4] H. Ma, N. Zhang, and L Qi, D. Sun, "Effects of different substrates and oils on aflatoxin $\mathrm{B}_{1}$ production by Aspergillus parasiticus." Eur. Food Res. Technol, vol. 240, pp. 627-634, 2015.

[5] M.J. Sweeney and A.D.W. Dobson, "Molecular Biology of Mycotoxin Biosynthesis," Microbiol. Lett, 1999, pp. 149-163.

[6] S. Dawar and A. Ghaffar, "Detection of aflatoxin in sunflower seed," Pak. J. Bot, vol. 23. no.1, pp. 123-126, 1991.

[7] N. Banu, "Muthumary, J. Aflatoxin $B_{1}$ contamination in sunflower oil collected from sunflower oil refinery situated in Karnataka," Health, vol.2, pp. 974-987, 2010.

[8] A.O. Elzupir, M.A. Suliman, İ.A. İbrahim, M.H. Fadul and A.M. Elhussein, "Aflatoxins levels in vegetable oils in Khartoum State, Sudan," Mycotoxin Res. vol.26, pp.69-73, 2010.

[9] S. Chulze, E. Varsavsky, S. Fusero, A. Dalcero and C. Farnochi, "Effect of the Lipid Fraction of Sunflower Seeds on Aflatoxin Production by Aspergillus Parasiticus,". Mycol. Res. vol.95, no.2, pp. 254-256, 1991.

[10] A.A. Mariod, and Y.M.A. Idris, "Aflatoxin $B_{1}$ levels in groundnut and sunflower oils in different Sudanese states," Food Addit. Contam. Part B. vol.8, no.4, pp. 266-270, 2015.

[11] K. Bordin, M.M. Sawada, C.E.C. Rodrigues, C.R. Fonseca and C.A.F. Oliveira, "Incidence of aflatoxins in oil seeds and possible transfer to oil: a review," Food Eng. Rev. vol. 6, pp. 20-28, 2014.

[12] S.C. Basappa and V.J. Sreenivasamurthy, "State of aflatoxin in groundnut oil," Food Sci. Technol, vol. 11, pp.137-140, 1974.

[13] W.A. Parker and D. Melnick "Absence of aflatoxin from refined vegetable oils," J. Am. Oil Chem. Soc. vol.43, pp. 635-638, 1966.

[14] U.S. Pal, R.K. Patra, N.R. Sahoo, C.K. Bakhara and M.K. Panda, "Effect of refining on quality and composition of sunflower oil," $J$. Food Sci. Technol. vol. 52, no.7, pp. 4613-4618, 2015.

[15] AOAC Official Method 991.31. Aflatoxins in corn, raw peanuts, and peanut butter. Immunoaffinity Column (Aflatest) Method, First Action 1991, Final Action 1994.

[16] EURACHEM. The fitness for purpose of analytical methods. A laboratory guide to method validation and related topics. Middlesex, TW11 0LY, United Kingdom: EURACHEM Working Group. 1998.

[17] C. Das and H.N. Mishra, "Effect of aflatoxin $B_{1}$ detoxification on physicochemical properties and quality of ground nut meal," Food Chem. vol.70, pp. 483-487, 2000.

[18] L.Bao, C. Liang, M.W. Trucksess, Y. Xu, N. Lv, Z. Wu, P. Jing and F.S. Fry, "Determination of aflatoxins $B_{1}, B_{2}, G_{1}$ and $G_{2}$ in olive oil, peanut oil and sesame oil using immunoaffinity column cleanup, postcolumn derivatization, and liquid chromatography/fluorescence detection: collaborative study," J. AOAC Int. vol.95, no.6, pp.1689$1700,2012$.

[19] L. Afsah-Hejri, S. Jinap, S. Arzandeh and H. Mirhosseini, "Optimization of HPLC conditions for quantitative analysis of aflatoxins in contaminated peanut," Food Control, vol. 22, pp.381$388,2011$.

[20] J.A. Mmongoyo, F. Wu, J.E. Linz, M.G. Nair, J.K.Mugula, R.J. Tempelman and G.M. Strasburg, "Aflatoxin levels in sunflower seeds 
and cakes collected from micro- and small-scale sunflower oil processors in Tanzania," Plos One, vol.12, no. 4, pp.1-14, 2017.

[21] (EC) European Commission. Commission Regulation (EC) No 401/2006 of 23 February 2006 laying down the methods of sampling and analysis for the official control of the levels of mycotoxins in foodstuffs. OJEU. L70/31, 2006.

[22] N. Mahoney and R.J. Molyneux, "A rapid analytical method for determination of aflatoxins in plant-derived dietary supplement and cosmetic oils," J. Agric. Food Chem., vol.58, no.7, pp.4065-4070, 2010.

[23] H. Yazdanpanah, T. Mohammadi, G. Abouhossain and A.M. Cheraghali, "Effect of roasting on degradation of aflatoxins in contaminated pistachio nuts," Food Chem. Toxicol., vol.43, pp.11351139, 2005.

[24] H.R. Pluyer, E.M. Ahmed and C.I. Wei "Destruction of aflatoxin on peanut by oven and microwave roasting," J. Food Prot., vol.50, pp. 504-508, 1987.

[25] S. Arzandeh and S. Jinap "Effect of initial aflatoxin concentration, heating time and roasting temperature on aflatoxin reduction in contaminated peanuts and process optimisation using response surface modelling," Int. J. Food Sci. Technol., vol. 46, pp. 485-491, 2011.

[26] I.Y.S. Rustom, "Aflatoxin in food and feed: occurence, legistation and inactivation by physical methods," Food Chem., vol. 59, no. 1, pp.57-67, 1997.

[27] G.E. Mann, L.P. Codifer and F.G. Dollear, "Effect of heat on aflatoxin in oilseed meals," J.Agricul. Food Sci., vol. 15, pp. 1090$1092,1967$.

[28] B. Kabak, A.D.W. Dobson and I. Var, "Strategies to prevent mycotoxin contamination of food and animal feed: a review," Crit. Rev. Food Sci. Nutr., vol. 46, pp. 593-619, 2006.

[29] Turkish Standards Institute, Sunflower Seeds TSE. 309- 2010.

[30] Y.L. Zheng, D.P. Wiesenborn, K. Tostenson and N. Kangas, "Energy analysis in the screw pressing of whole and dehulled flaxseed," J. Food Eng., vol. 66, pp. 193-202, 2005.

[31] I. Var, Ö. Atasever Savaş, S. Sağlam and O. Uçkun, "The effect of fermentation and cooking process on the amount of OTA in breads," Food, vol.43, no.6, pp.1053-1060, 2018.

[32] (TGK) Turkish Food Codex, Contaminants Regulation. Official Gazette, No: 28157 (3rd Repeat). 29.12.2011.

[33] EEC. Council Directive 74/63/EEC on the fixing of maximum permitted levels for undesirable substances and products in feedingstuffs. OJEC. 1974. No. L 38.

[34] S. Uluata, "Characterization of some vegetable oils," Ph.D. Thesis, Department Chemistry Institute of Science, İnönü University, Malatya, pp.116, 2010.

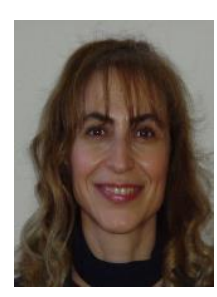

Var I. is a professor at the Department of Food Engineering, Çukurova University, Adana, Turkey. She gives the lectures and also study about General Microbiology, Food Safety, Food Microbiology, Food Hygiene and Sanitation, Food Biotechnology, Mycotoxins, Molecular Biology.

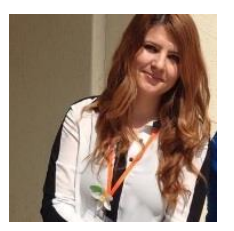

Uçkun O. graduated from Çukurova University, Department of Food Engineering in 2009. She got her Master's Degree and $\mathrm{PhD}$ at Çukurova University, Department of Food Engineering. She started to work as a food controller in Artvin / Ardanuç District Directorate of Food, Agriculture and Livestock in 2012. In 2014, she was appointed as the Directorate of Osmaniye Oil Seeds Research Institute. In 2017, she was appointed to Adana Food Control Laboratory, where she is still working. 